\title{
IAMJ
}

INTERNATIONAL

AYURVEDIC

MEDICAL JOURNAL

ISSN: 2320-5091

Impact Factor: 6.719

\section{A CASE REPORT REGARDING MANAGEMENT OF GRAHANI DOSHA THROUGH AYURVEDA}

\section{Charu Sharma}

Associate Prof. Department of Kaya Chikitsa, Quadra Institute of Ayurveda, Roorkee, Haridwar, Uttarakhand, India

Corresponding Author: charu22jan@gmail.com

https://doi.org/10.46607/iamj5209082021

(Published Online: August 2021)

Open Access

(C) International Ayurvedic Medical Journal, India 2021

Article Received: 31/07//2021 - Peer Reviewed: 11/08/2021 - Accepted for Publication: 12/08/2021

\section{Check for updates}

\section{ABSTRACT}

Grahani as an organ is considered as the seat of Agni which is supported and nourished by Agni with Aadhara Aadheya Sambandha. This Agni is vitiated by Ama formed because of improper diet and regimen. Among them, Grahani dosha is the prime disease and is seen often in day-to-day practice. Material And Method: A 32-yearsold male patient was coming to the OPD of Kaya Chiktsa, Quadra Institute of Ayurveda with complaints of defecation just after taking a meal, Bowelfrequency 4-5 times/day, irregular bowel habit, loss of appetite, generalized weakness, occasional pain in the abdomen, slow weight gain. These complaints were persisting for the past1 year. This condition can be understood as Grahani Dosha, treatments including with somemedicine course of 2 months. Result: There were significant improvements in the condition of the patient. Discussion: while treating Grahani, the drugs alleviating Vata, Pitta, Doshas, which are having Deepan, Pachana, Grahi, Stambhana as well possessing tikta, katu rasa and ushna veerya should be selected. there was a significant reduction in all the signs and symptoms ofthe disease are observed. Conclusion: A meticulous planning of treatment considering the Bala, and Agni of patient accompanied with proper diet will provide encouraging results in treating Grahani Dosha.

Keywords: Grahani dosha, Agni, Aama, Stambhana. 


\section{INTRODUCTION}

Approximately $20 \%$ of the general population fulfils diagnostic criteria for irritable bowel syndrome (IBS). It is generally believed that most patients develop symptoms in response to psychosocial factors, altered gastrointestinal motility, altered visceral sensation or luminal factors ${ }^{[1]}$ Acharya Charaka stated that Grahani is situated above Nabhi (umbilicus), the strength of Agni nourish and support the Grahani, digest the food and releases into the next Ashaya i.e., Pakvashaya ${ }^{[2]}$ Because of the impairment of Agni it releases food in undigested form. As per Acharya Sushrta Grahani is the 6th Pittadhara Kala situated between Amashaya (Stomach) and Pakwashaya. ${ }^{[3]}$ Acharya Sushruta mentioned that if an Atisara patient enjoys an unjust diet during the Agnimandya stage, it may lead to Grahani Roga. ${ }^{[4]}$ If a person consumes the food incorrectly is responsible for Grahani Dushti, especially in a person with disturbed digestion and cause the disease Grahani. Acharya Chakrapani mentioned that Ashraya is Grahani, and Ashrita is Agni. ${ }^{[5]}$ In Ayurveda, an exact correlation cannot be found of IBS but according to signs and symptoms and pathology of disease, we can consider this clinical entity as Grahani Dushti. In the present study through the case was diagnosed as Grahani (IBS), the patient had GIT symptoms and general symptoms related to Grahani. Hence the patient was administered Deepan, Pachan, Grahi oral medication.

Case History: A 32-year-old male patient was brought to the OPD of Kaya Chikitsa, Quadra Institute ofAyurveda Roorkee, Haridwar by his brother with complaints of

a) defecation just after taking a meal, Bowel fre- quency 4-5 times/day

b) irregular bowel habit

c) loss of appetite

d) generalized weakness,

e) occasional pain in the abdomen

f) slow weight gain

These complaints were persisting for the past 1 year.

History of Present Illness: The patient was healthy 1 year back. Then he gradually developed defecation just after taking a meal, Bowel frequency 4-5 times/day, irregular bowel habit, loss of appetite generalized weakness. At the outset, the family have taken him for consultation in a nearby hospital, where they have given a course of medications, which they have taken, but did notget any satisfactory relief. As days passed, he faced more irregular bowel habits (5-7 times), loss of appetite generalized weakness occasional pain in the abdomen, slow weight gain. Thecondition got aggravated for the last 15 -20 days. Then, he decided to come for a better evaluation and management in Quadra Institute of Ayurveda, Roorkee, Haridwar. After a thorough interrogation regarding the diet, lifestyle, and habits him the history of the present illness and after a proper evaluation regarding the present condition of the child, he was admitted to the IPD of Kaya Chikitsa of our hospital and planned for internal medications.

History of Patient - The patients used antacid and antispasmodic drugs unevenly. His family history revealed that there were no such complaints ever.

\section{Asthavidha Pariksha -}

Assessment of the general condition of the patient:

Table 1: Asthavidha Pariksha

\begin{tabular}{|l|l|}
\hline Naadi & Kaphaja \\
\hline Mala & Samanya \\
\hline Jivha & Malavrit \\
\hline Sabada & Samanya \\
\hline Spersha & Snigdha \\
\hline Driga & Samanya \\
\hline Aakriti & Samaakriti \\
\hline
\end{tabular}




\section{On Local Examination Clinical Finding As}

On examination of the patient, mild pallor was present, and his vitals were within normal limit. Appetite and sleeping pattern were normal, altered bowel habits i.e., 5-7-time, loss of appetite, generalized weakness, occasional pain in the abdomen, weight loss. Micturition frequency was also increased (8-10 times). No abnormality was detected in CVS, CNS, and RS. Tenderness is present in P/A examinations.

Diagnosis - Grahani (irritable bowel syndrome)

Date of attending OPD-30/04/2021 Treatments

\section{Given}

A single course of treatment is given for 15 Days.

Table 2: Asthavidha Pariksha

\begin{tabular}{|l|l|}
\hline Avipattikar churna & $3 \mathrm{gm}$ \\
\hline Bilva Churna & $1 \mathrm{gm}$ \\
\hline Panchamrut parpati & $300 \mathrm{mg}$ \\
\hline Sutsekhar Rasa & $250 \mathrm{mg}$ \\
\hline & $1 \times 2$ with Takra before a meal. \\
\hline
\end{tabular}

1. Sankha Vati - 1tab BID

2. Kutajghan vati - 2-tab TID

3. Kutajarishta $-20 \mathrm{ml}$ BID

Table 3: Showing Grading for clinical features.

\begin{tabular}{|c|c|c|c|c|c|c|c|}
\hline \multirow[t]{2}{*}{ Clinical Features } & \multirow{2}{*}{\multicolumn{2}{|c|}{ Grading }} & \multirow{3}{*}{$\begin{array}{l}\text { BT } \\
4\end{array}$} & \multicolumn{3}{|l|}{ AT } & \multirow{3}{*}{$\begin{array}{l}\text { \% of Relief } \\
100\end{array}$} \\
\hline & & & & \multirow{2}{*}{$\begin{array}{l}15 \text { days } \\
3\end{array}$} & \multirow{2}{*}{$\begin{array}{l}30 \text { days } \\
1\end{array}$} & \multirow{2}{*}{$\begin{array}{l}60 \text { days } \\
0\end{array}$} & \\
\hline Muhurbaddhamu & Passing normal & 0 & & & & & \\
\hline hurshithil mala & consistency & & & & & & \\
\hline (Altered bowel & stool(1time/day) & & & & & & \\
\hline \multirow[t]{17}{*}{ habit) } & Passing stoolirregular (1-2 & 1 & & & & & \\
\hline & /day) & & & & & & \\
\hline & without pain & & & & & & \\
\hline & Passing stool & 2 & & & & & \\
\hline & irregular $(2-3$ & & & & & & \\
\hline & times/day) with & & & & & & \\
\hline & pain & & & & & & \\
\hline & Passing stool & 3 & & & & & \\
\hline & irregular \& just & & & & & & \\
\hline & after a meal (3-4 & & & & & & \\
\hline & times/day) with & & & & & & \\
\hline & pain & & & & & & \\
\hline & Passing stool & 4 & & & & & \\
\hline & irregular \& just & & & & & & \\
\hline & after meal & & & & & & \\
\hline & (>4times/day) & & & & & & \\
\hline & with pain & & & & & & \\
\hline Aruchi & Taking normal & 0 & 1 & 1 & 0 & 0 & 100 \\
\hline \multirow[t]{3}{*}{ (anorexia) } & diet & & & & & & \\
\hline & interest & & & & & & \\
\hline & No interest in & 1 & & & & & \\
\hline
\end{tabular}




\begin{tabular}{|c|c|c|c|c|c|c|c|}
\hline & taking normal & & & & & & \\
\hline & diet & & & & & & \\
\hline & Food has taken & 2 & & & & & \\
\hline & forcefully & & & & & & \\
\hline & Not taken a & 3 & & & & & \\
\hline & food even & & & & & & \\
\hline & forcefully & & & & & & \\
\hline $\begin{array}{l}\text { Balakshya } \\
\text { (Weakness) }\end{array}$ & No weakness & 0 & 2 & 2 & 1 & 1 & 50 \\
\hline
\end{tabular}

\begin{tabular}{|c|c|c|c|c|c|c|c|}
\hline & Weakness butperforms day to day activities & 1 & \multirow[b]{7}{*}{2} & \multirow[b]{7}{*}{2} & \multirow[b]{7}{*}{1} & & \multirow[b]{7}{*}{50} \\
\hline & $\begin{array}{l}\text { Weakness \& } \\
\text { difficulty inperforming daytoday }\end{array}$ & 2 & & & & & \\
\hline & Cannot be able toget up from bed & 3 & & & & & \\
\hline \multirow[b]{4}{*}{ Klama (Exhaustion) } & No exhaustion & 0 & & & & & \\
\hline & Exhaustion withmoderate work & 1 & & & & & \\
\hline & Exhaustion withmild work & 2 & & & & \multirow[b]{2}{*}{1} & \\
\hline & Exhaustion without effort & 3 & & & & & \\
\hline & No complaint & 0 & & & & & \\
\hline & Occasionally & 1 & & & & & \\
\hline Antrakunjan (Gurgling soundin abdomen) & 2-3 times/daybefore passingstool & 2 & & & & & \\
\hline & Persistent & 3 & 3 & 2 & 1 & 0 & 100 \\
\hline & No visiblemucous in stool & 0 & & & & & \\
\hline & Visible mucousstickled to thestool & 1 & & & & & \\
\hline & Passage of mucous with frequent stool & 2 & & & & & \\
\hline Passing mucus instool & Passage of a largeamount ofmucous in stool & 3 & 2 & 2 & 1 & 0 & 100 \\
\hline
\end{tabular}

\section{OBSERVATIONS AND RESULTS}

The follow up was made on the 15th day, 30th day and 60th day. During this period patient did not develop any other complaints. The patient reported gradual improvement in altered bowel habits, stool with mucus, pain in the abdomen, anorexia, indigestion, heaviness in the abdomen. After treatment patient got significant relief and he gained weight up to $54 \mathrm{~kg}$. (Before treatment wt. $51 \mathrm{~kg}$ )

Follow Up After Treatment: After discharging from the hospital patient is advised to continue with Kutaj Ghana Vati 1 TDS and Kutajarishta 10ml BD with water.

Discussion On Disease: In the present case, the patient presented with complaints of defecation just after taking a meal, Bowel frequency 4-5 times/day, irregular bowel habit, loss of appetite, generalized weakness, occasional pain in the abdomen, weight loss. These complaints were persisting for the past 1 year. This condition can be understood as "Grahani", treatments including with some medicine course of 2 months. Vata and Pitta are involved in the manifestation of Grahani (IBS), the characteristic feature of Grahani is Muhurbaddhamuhurshithil mala, Aruchi, balakshaya, trushina, klama, and Antrakunjan.

Discussion on Treatment: The cardinal features of Grahani, in our classical texts, are like that of IBS in contemporary science. Grahani is a syndrome in which Agni becomes depressed, Ama Dosha (undigested waste material) accumulates \& passes in the stool. Through, Vata and Pitta are involved in the manifestation of Grahani. So, while treating Grahani, the drugs alleviating Vata \& Pitta doshas, and enhance the potency of Agni should be selected. Avipattikar Churna is also used for Agnimaandjanya diseases ${ }^{[6]}$. Avipattikar Churna corrects the action of Apan Vata, which helps in the proper flow of faeces. Bilva has Kashaya \& Tikta Rasa, Laghu \& Ruksha 
Guna, Ushna Veerya, Katu Vipaka and Deepan, Paachan, Graahi, Vata- Kaphahara properties. Bilva have Sangraahik properties. So Bilva binds up and hold the stool and helps in decreasing the frequency of loose motion. Panchamruta Parpati was described under thenGrahaniroga Chikitsaadhyay in Bhaishajyaratnavali. According to Ayurveda properties of Panchamruta Parpati includes Deepan (stimulation of Agni), Pachan (digestive), Grahi (carminative), Laghu (decreases Ama). ${ }^{[7]}$ Ushna Guna and Deepan properties increase appetite, Grahi property improvesabsorption of nutritive material. Takra (buttermilk) is the best Anupan mentioned in Grahani Chikita. Acharya Sadananda Sharma has described the properties of Shankha Bhasma in Ras Tarangini.It is indicated in GIT disorders like Grahani Roga (IBS), Atisara (diarrhoea), Amlapitta (Hyperacidity) and it shows Balya, Grahi (carminative) effects. ${ }^{[8]}$ Kutaj has Tikta \& Kashaya Rasa, Sheeta Veerya, Katu Vipaka and Deepan, Stamabhan,Pittakapha Shamaka properties ${ }^{[9]}$ Due to the above properties Kutaj has stimulated Agni, which leads to removing Ama (toxin) formation by proper digestion of food and Ama. Due to Tikta \& Kashaya Rasa, Ruksha Guna and Sheeta Veerya, it pacifies the Kapha \& Pitta Dosha.

\section{CONCLUSION}

Faulty dietary habits and changes in lifestyle patterns are the important cause of this disease. So, correction of diet patterns and lifestyle modification is mandatory. As the treatment given here showed good remarkable improvement and response along with strict diet regimen gave us a hope and a new finding was found successful as a possible effective Ayurvedic cure in Grahani (IBS) Roga. Based on the above discussion, it can be concluded that Ayurvedic treatment is very successful in the management of Grahani (IBS). It is easily adaptable in routine practice and safe, costeffective and has no side effects.

\section{REFERENCES}

1. Nicholas A. Boon, Christopher Haslett, Edwin R. Chilvers, John A.A. Hunter, Davidson's Principles
andPractice of Medicine 18th Edition, Chapter, 9: 668.

2. Anna Moreshwar Kunte, Krishnashastri Navre, Ashtanghridayam (Sutra Sthana), Choukhamba PrakashanVaranasi; 2010 p.193.

3. Ambikadatta Shastri, Hindi commentary, Sushruta Samhita (Uttar Tantra), Atisar Pratised Adhyay, Choukhamba Sanskrit Sansthan Varanasi; 2012 p.306.

4. Shastri Ambikadutta, Susruta Samhita Vol.-II, (Uttartantra). Varanasi, Chaukhambha Sanskrit Sansthan,2012. p.335.

5. Shastri Pt Kashinath \& Chaturvedi Dr Gorakha Natha, Charak Samhita, Part-2, (Charak Chikitsasthana) Varanasi, (India), Chaukhambha Bharti Academy, Reprint 2013, p. 462.

6. Shri Ambika data Shastri, Shri Rajeshwardatta Shastri Ayurvedashashracharya; Bhaishajya Ratnavali with Hindi commentary; 8th edition; Varanasi; Chaukhambha Sanskrit Sansthan; 1987; Page no-643-44.

7. Govindas Sen, Hindi commentary by Ambikadatta Shastri, Bhaishajyaratnavali, Grahani Roga Chikitsa Adhyay, Choukhamba Prakashan, Varanasi; 2016 p.278.

8. Sadananda Sharma, Edited by Pandit Kashinath Shastri, Rastarangini, Motilal Banarasidas, Delhi; 2014p.288.

9. Prof. P.V. Sharma; Dravya Guna-vijnana; Vol-2; Chapter no-5, Reprint 2012; Varanasi; Chaukhambha BhartiAcademy; Page no-465.

\section{Source of Support: Nil Conflict of Interest: None Declared}

How to cite this URL: Charu Sharma: A Case Report Regarding Management Of Grahani Dosha Through Ayurveda. International Ayurvedic Medical Journal \{online\} 2021 \{cited August 2021\} Available from: http://www.iamj.in/posts/images/upload/1920_1924.pdf 